\title{
Preliminary investigations of organics soil in a new calibration chamber with the use of the FVT and DPL probe
}

\author{
Grzegorz Straż ${ }^{1, *}$ \\ ${ }^{1}$ Departments Geodesy and Geotechnics, Rzeszow University of Technology, ul. Poznańska 2, \\ 35-084 Rzeszow, Poland
}

\begin{abstract}
The proposal of investigations of soft organic soils in a new calibration chamber performed at the Rzeszow University of Technology has been presented in this paper. The unique feature of this chamber is the possibility of simultaneous soil testing with the use of two penetrometers: FVT (Field Vane Test) and DPL (Dynamic Probing Light). It has been possible due to the large size of the cylindrical soil sample: $62.5 \mathrm{~cm}$ in diameter and max. $80 \mathrm{~cm}$ high. Additionally, a construction with a new calibration chamber has been described, concerning potential capabilities and restrictions when conducting researches. The presented calibration chamber ensures the stability of the parameters set during the tests, which allows one to compare the test results and search for the relationship between the analyzed parameters. Shear strength from the FVT test was adopted as reference. The results of preliminary research were presented and a detailed research plan was prepared, which will be implemented in the next stages of the investigations.
\end{abstract}

\section{Introducion}

Modern methods of ground base recognition conducted in situ conditions used for laying construction objects and engineering structures cover a wide spectrum of tests using various types of penetrometers, e.g.: static, dynamic, rotary probes, dilatometers, pressuremeters, etc. [1]. In the case of determination of undrained shear strength in soft soils, such as nonplastic mineral soil (non-cohesive) in very loose or loose condition, mineral plastic (cohesive) in the soft plastic and organic soils (gytias, muds and peats), the field vane tests (FVT ) proved to be a perfect solution [2]. Many years of practice has also proved its high suitability for estimating the state of plastic (cohesive) soils, including organic [3]. Field tests with a rotary probe are complicated due to the way the tip (steel vane blades) is inserted into the ground, and most importantly, they can be made pointwise, only for a specific, selected depth, and not in a continuous mode. The cone penetration (CPT) or piezocone tests (CPTU) are much simpler in this respect, but unfortunately, it is expensive. An indirect solution for obtaining information about the ground subsoil, with the measurement of results in a continuous mode with a step of $10 \mathrm{~cm}$ is a dynamic probing test

${ }^{*}$ Corresponding address: gstraz@prz.edu.pl 
- light version - DPL [4]. This type of penetrometer is economical in operation, easy to use and fast in operation. The dynamic probe was used primarily to assess the state of noncohesive soils by determining the density index $\left(\mathrm{I}_{\mathrm{D}}\right)$ or relative density (RD), but attempts were also made to determine the states of cohesive soils, e.g.by Frankowski [5] or Rybicki and Krokoszyński [6], who showed a correlation between the results of various types of probes, comparing the results of alternative research. One of the solutions that enable conducting comparative tests on soil samples of a similar structure, known parameters and in the precisely defined conditions are calibration chambers, which differ in construction solutions depending on the purpose [7-9]. This paper presents a proposal for a calibration chamber in order to study soft soils, mainly organic, whose novel element is in the form of the possibility of parallel testing, using two different penetrometers: FVT-rotary probe and the lightest dynamic probe DPL. The priority objective of this paper was to search for correlations between test results using selected penetrometers in the aspect of determining the states of the soils and at a later stage of undrained shear strength or overconsolidation ratio. The research is also aimed at demonstrating whether it is possible to exchange the Field Vane Test and Dynamic Probing Light penetrometers in order to recognize the subsoil built of different kinds of organic soils. A basic parameter was used to calculate undrained shear strength, which can be calculated based on bondary strength from DPL research. Undrained shear strength can be a basic parameter for determining the value of other parameters e.g. the states of cohesive soil in condition in situ. The calculation procedure of undrained shear strength is presented in the further part of the article.

\section{Calibration chamber specification}

\subsection{Construction}

The calibration chamber was constructed in the form of a steel cylinder made of steel sheet, reinforced with a stiffening frame made of closed steel sections. The inner diameter of the cylinder is $62.5 \mathrm{~cm}$, while its height is $99 \mathrm{~cm}$. Despite the large dimensions, the cylinder is not permanently connected to the frame structure, which allows a more convenient preparation of the soil sample for testing outside the test bench. The test stand is rigidly connected with the frame base with a remote control hydraulic cylinder, directing the load to the piston pressing the surface of the prepared test (Fig. 1).

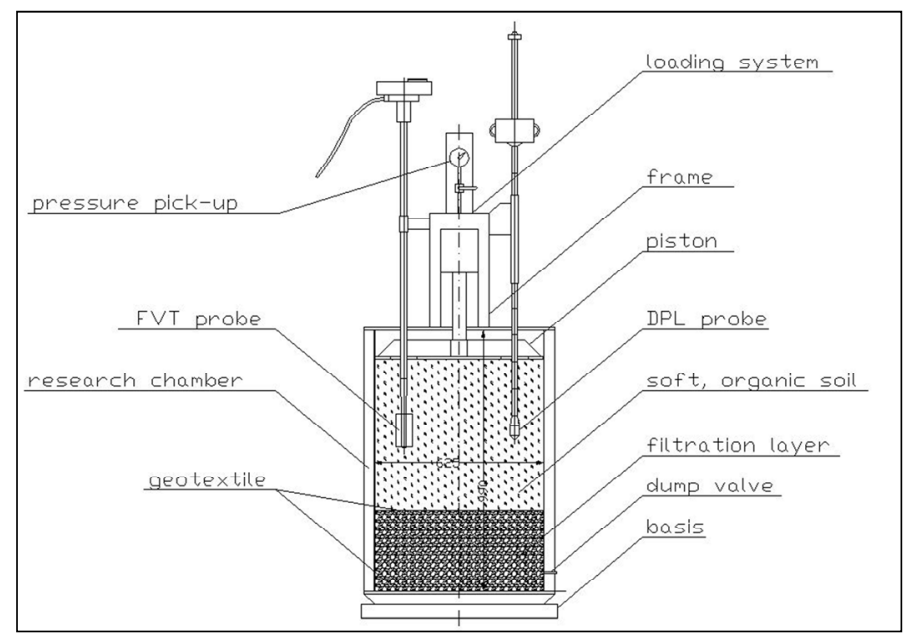

Fig. 1. The scheme of calibration chamber for the tests of organic soils using a FVT and DPL probe. 
In the lower part of the chamber there are cushions of PPC-300 separation-filtration geotextile filled with gravel of 4-8 $\mathrm{mm}$ grain size, constituting a filtration layer with a thickness of approx. $30 \mathrm{~cm}$. The ground material for testing in the chamber was also placed in the PPC-300 separation-filtration geotextile housing and protected against moisture loss from the top with a PE plastic film base of $0.3 \mathrm{~mm}$ thickness. Additionally, the layer of the tested soil was separated from the filtering layer by a spacer made of a separating and filtering geotextile PS $400 \mathrm{C}$. At the height of $7 \mathrm{~cm}$ and $55 \mathrm{~cm}$ from the bottom of the chamber there are valves enabling, depending on test conditions, water drainage or connection of water pressure measuring sensors in the tested ground material sample. It is also possible to mount piezometric tubes to observe changes in water conditions during the test.

\subsection{Loading system}

The stress in the calibration chamber is realized by the piston pressing the sample, controlled by a hydraulic cylinder, and the load control is carried out through a pressure sensor, correlated with the given force and stress. The hydraulic loading system has the ability to smoothly stress the chamber, which can reach up to $800 \mathrm{kPa}$. The correctness of the sensor's readings has been verified by an appropriate calibration test using the data acquisition system HBM Quantum X type MX-84A with a force sensor with a range of up to $200 \mathrm{kN}$. The stability of the force sensor was checked earlier and the observed deviations didn't exceed $\pm 6 \mathrm{~N}$.

\subsection{Applied research soundings}

Holders leading the rods of selected penetrometers were attached to the frame and openings were designed in the piston's surface with movable whole plugs, opened only for the time of entering the probe. The use of such a solution means that the surface to which the soil may be relaxed is limited, because at the same time the remaining openings are blinded and together with the surface of the piston take part in the process of loading the research soil material (Fig. 2).

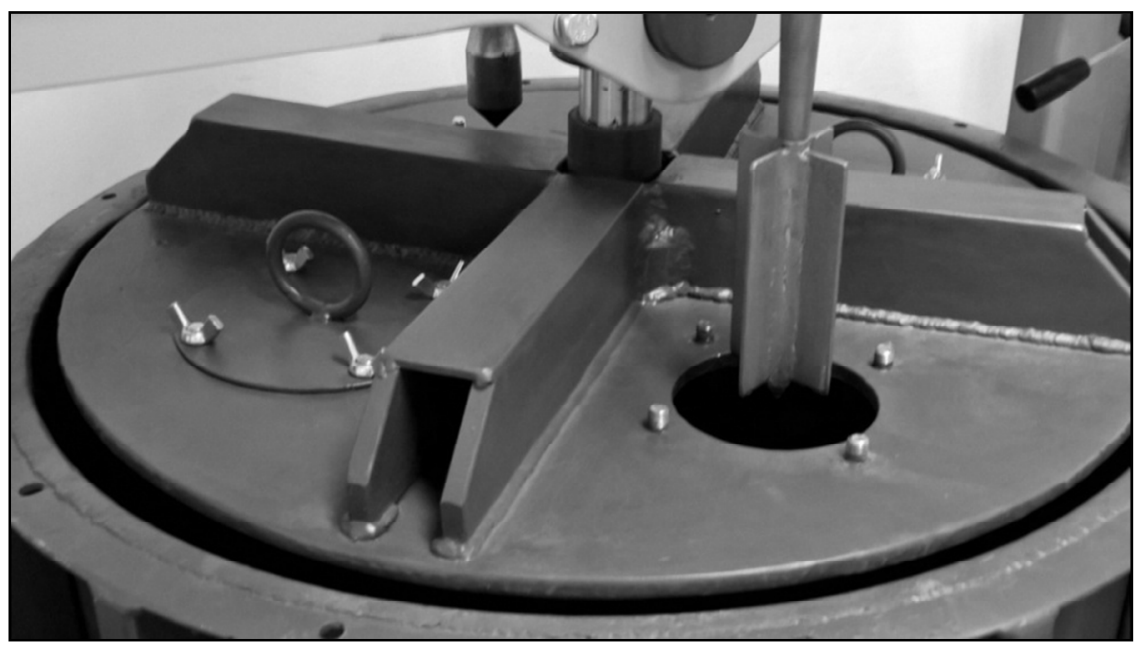

Fig. 2. The construction of the piston loading the soil in the calibration chamber. 
Normal probe tips can be used for testing in the chamber without the need for miniaturization. In the case of the FVT probe, these are cross-tips: $40 \times 80 \mathrm{~mm}, 60 \times 120 \mathrm{~mm}$ and $80 \times 160 \mathrm{~mm}$ rotated by means of an electric motor, whereas for the DPL probe, the tip is a cone with an angle of 90 degrees, nominal surface area $10 \mathrm{~cm}^{2}$ and is manually penetrated in the soil. Both the piston and the chamber can rotate with respect to its own axis, which allows the probe to be inserted in selected places of the prepared sample or to take samples for alternative laboratory tests.

According to the literature guidelines [10], the distance between FVT probes should not be less than 3 diameters of the tip, adequately 120,180 and $240 \mathrm{~mm}$ in a straight line. Depending on the size of the tip, it is possible to arrange from 4 to 8 points on the circumference, theoretically eliminating the influence of neighbouring probings (Fig. 3). Due to the high sample height in the chamber (about $700 \mathrm{~mm}$ ), it is possible to perform tests with the FVT probe at two different depths.

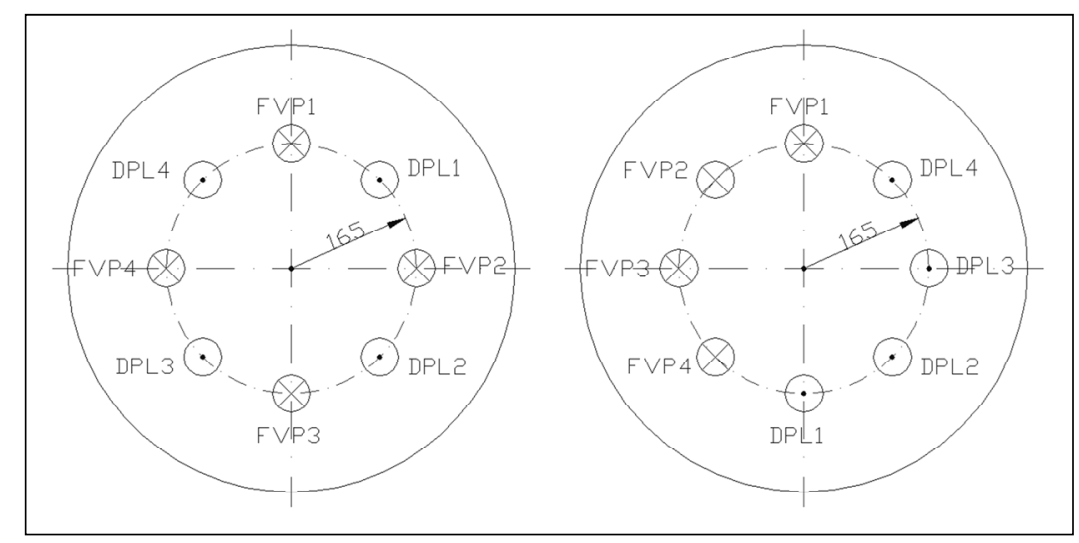

Fig. 3. The scheme of exemplary distribution of points field vane testing (FVT) and dynamic probing (DPL) in the calibration chamber.

It should be remembered that the cutting should not take place within 5 minutes at a rotational speed of about $5 \pm 0,5$ degree per minute. In the case of the DPL method, probing takes place over the entire height of the sample. Summing up, thanks to the possibility of rotation of the chamber in the frame with respect to the piston axis, each of the prepared samples can theoretically be used to perform even several strength tests.

In addition, after the endurance tests in the chamber, it is possible to take samples with identical parameters for alternative comparative tests, e.g. in the direct shear testing or triaxial shear testing because the chamber allows testing with varying accuracy: the exact and approximate method. The exact method consists in examining one sample only once, with one amount of stress in the chamber, whereas a change in stress causes the need to prepare a new sample each time. In the approximate method, one sample can be tested several times at different stress setpoints in the chamber. The organic soil material remaining after the tests can be used, for example, to determine the consistency of laboratory methods, chemical and mineral composition, organic matter content or the degree of decomposition. 


\section{Characterization of ground research material}

\subsection{Characteristic of the study area}

The sampling of organic soil was conducted in the south-eastern part of Rzeszow in Poland, where during the investment-housing estate, multi-family residential building with technical and communication infrastructure. In terms of morphology, this area is located within the terrace of the Młynówka river, rising in this region to the height of 205.0-207.1 m above sea level. The area in the analyzed area is almost flat, and the denivelation is about $0.5-0.7 \mathrm{~m}$. Local organic soils were localized about below 1,7-4,0 meters under the surface and was originated from the Holocene [11]. Generally these soils were wet and moisture peats mixed with organic muds (siOr, clOr), sandy silts ( $\mathrm{saSi}$ ) and medium sands (MSa) [12]. Acquiring samples of organic soils is very difficult and complicated, mainly due to the compressibility of the material and retention mainly below the ground water table $[13,14]$, therefore samples for laboratory analyses in a new calibration chamber structure were collected with the disturbed, while drilling CFA piles.

\subsection{Preparation of soil material}

The soil material with natural moisture was thoroughly ground and mixed to achieve the most uniform structure possible and then placed in the chamber with layers of approx. $10 \mathrm{~cm}$ thick, slightly compacting. After reaching the height of about $70 \mathrm{~cm}$, the sample was covered from the top with foil, protecting against moisture loss and subjected to initial consolidation stress of $15 \mathrm{kPa}$ and left under the load for a period of time necessary to stabilize the system. Averaged values of basic geotechnical parameters of soil testing in the calibration chamber determined on the basis of laboratory and field tests are presented in table 1.

Table 1. Basic average parameters of soil testing in calibration chamber.

\begin{tabular}{|c|c|c|c|c|c|c|}
\hline $\begin{array}{c}\text { Type of } \\
\text { organic soil }\end{array}$ & $\begin{array}{c}\text { Soil } \\
\text { moisture }\end{array}$ & $\begin{array}{l}\text { Organic } \\
\text { content }\end{array}$ & Soil & $\begin{array}{c}\text { Unit } \\
\text { weight }\end{array}$ & $\begin{array}{c}\text { Consistency } \\
\text { index }\end{array}$ & Consistency \\
\hline $\begin{array}{l}\text { included in } \\
\text { the layer }\end{array}$ & $\mathrm{M}[\%]$ & $\mathrm{I}_{\mathrm{om}}[\%]$ & \multirow{2}{*}{$\begin{array}{l}\text { high- } \\
\text {-organic }\end{array}$} & $\gamma\left[\mathrm{kN} / \mathrm{m}^{3}\right]$ & $\mathrm{I}_{\mathrm{C}}[-]$ & \multirow[b]{2}{*}{ soft } \\
\hline $\begin{array}{l}\text { Peat//saSi, } \\
\text { Peat//Muds, } \\
\text { Peat//MSa }\end{array}$ & 131.39 & 41.01 & & 11.05 & 0.40 & \\
\hline
\end{tabular}

\section{Results of preliminary tests}

The tests were aimed at determining the suitability of the calibration chamber for determining the strength parameters of soft, organic soils using the FVT and DPL penetrometers. Derived value of geotechnical parameters obtained from test results was the basis for looking for a relationship between derived strength parameters in both probes. Undrained shear strength from field vane test and boundary strength of soil from dynamic probing were compared. The consistency of the soil on the basis of shear strength of field vane tests was also estimated according to the Polish standard [15].

\subsection{Undrained shear strength from FVT}

The basis of the calculations was the measured maximum value torque shear on the vane. For standard vanes with $\mathrm{D} / \mathrm{H}=1: 2(\mathrm{D}=60 \mathrm{~mm}, \mathrm{H}=120 \mathrm{~mm})$ the measured shear strength $\mathrm{c}_{\mathrm{fv}}$ value could be determined by using the formula [15]: 


$$
c_{f v}=\frac{T_{\max ; u}}{\pi D^{2}\left(\frac{H}{2}+\frac{D}{6}\right)}=0.273 \frac{T_{\max ; u}}{D^{3}}
$$

where: $\mathrm{T}_{\max ; \mathrm{u}}-$ maximum torque on the vane, $\mathrm{D}$-diameter of vane shaft.

Multiannual empirical studies have shown that the value of undrained shear strength $c_{\mathrm{fu}}$ calculated on the basis of directly measured values by field vane are inflated and needs to be corrected by correction factor $\mu$ before it can be used in formula:

$$
c_{f u}=c_{f v} \mu
$$

where: $\mathrm{c}_{\mathrm{fv}}-$ measured shear strength, $\mu$ - correction factor.

In Polish conditions, depending on the type of organic soil and its leading parameters, the value of the correction factor is usually taken in the range from 0.45 to 0.80 [16]. It wasn't the subject of this article and that is why, here the correction factor assumed equals 1.0 , therefore $c_{\mathrm{fu}}$ is the same as be $c_{\mathrm{vf}}$. Additionally, the sensitive field vane test $\mathrm{S}_{\mathrm{fv}}$ was specified and it estimated the index of soil's sensitivity [14]:

$$
S_{f v}=\frac{c_{f u}}{c_{r e s ; v f}}
$$

where: $c_{\mathrm{fu}}$-shear strength, $\mathrm{c}_{\mathrm{res} ; \mathrm{vf}}$ shear strength after peak shear has been exceeded and a constant shear strength value is the measurement of total rotation of $180^{\circ}$.

\subsection{Boundary strength from dynamic probing}

Boundary strength of soil under cone DPL calculate according to the Dutch formula [15]:

$$
q_{d}=\frac{m}{m+m^{\prime}} r_{d}=\frac{m}{m+m^{\prime}} \frac{m g h}{A e}
$$

where: $r_{d}$ - resistance values, $m-$ mass of the hammer, $h$ - height of fall of the hammer, $\mathrm{g}$ - acceleration due to gravity, A - nominal base area of the cone, $\mathrm{e}-$ average penetration, in $\mathrm{m}$ per blow, $\mathrm{m}$ '- total mass of the extension rods, the anvil and guiding rod.

Table 2. Basic parameters for dynamic probing apparatus DPL.

\begin{tabular}{|c|c|c|c|c|c|}
\hline $\begin{array}{c}\text { Hammer } \\
\text { mass }\end{array}$ & $\begin{array}{c}\text { Falling } \\
\text { height }\end{array}$ & $\begin{array}{c}\text { Acceleration } \\
\text { due to gravity }\end{array}$ & $\begin{array}{c}\text { Nominal base } \\
\text { area of the cone }\end{array}$ & $\begin{array}{c}\text { Cavity of } \\
\text { the cone }\end{array}$ & $\begin{array}{c}\text { Drive rod, anvil and } \\
\text { hammer guide mass }\end{array}$ \\
\hline $\mathrm{m}[\mathrm{kg}]$ & $\mathrm{h}[\mathrm{m}]$ & $\mathrm{g}[\mathrm{N} / \mathrm{kg}]$ & $\mathrm{A}\left[\mathrm{m}^{2}\right]$ & $\mathrm{e}[\mathrm{m}]$ & $\mathrm{m}$ ' $[\mathrm{kg}]$ \\
\hline $10 \pm 0.1$ & $0.5 \pm 0.01$ & 9.81 & 0.001 & $0.1 / \mathrm{N}_{10}$ & 9.0 \\
\hline
\end{tabular}

The calculations are made on the basis of the measured depth of penetration per one blow of hammer and characteristic parameters of dynamic probe (table 2). 


\subsection{Analysis of test results}

Strength tests in the calibration chamber were carried out at known vertical pressure values: $26 ; 48 ; 66 ; 92$ and $115 \mathrm{kPa}$, corresponding to the research series. Restrictions on the pressure values adopted resulted from the accuracy of the pre-installed control system. Each research series included FVT probes at selected points at a depth corresponding to $1 / 3$ and $2 / 3$ of the sample height and DPL probes. Based on the values measured during the tests (maximum torque and average penetration: number blow per in $0,1 \mathrm{~m}$.), adequate derived values were determined (undrained shear strength from FVT and boundary strength under cone DPL). Detailed results are presented in table 3.

Table 3. Preliminary results of tests of organics soil in a new calibration chamber.

\begin{tabular}{|c|c|c|c|c|c|c|}
\hline \multirow[b]{2}{*}{$\begin{array}{l}\text { Pressure } \\
\text { in } \\
\text { chamber }\end{array}$} & \multicolumn{3}{|c|}{ Field Vane Test } & \multicolumn{3}{|c|}{ Dynamic Probing } \\
\hline & 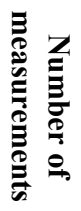 & 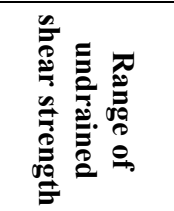 & 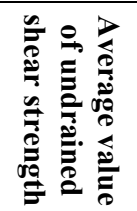 & 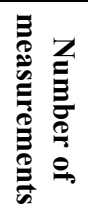 & 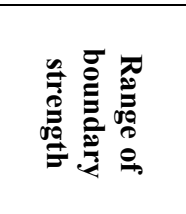 & 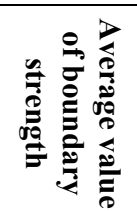 \\
\hline$\sigma[\mathrm{kPa}]$ & $\mathrm{n}[-]$ & $\mathrm{c}_{\mathrm{vf}}[\mathrm{kPa}]$ & $\mathrm{c}_{\mathrm{vf} ; \mathrm{a}}[\mathrm{kPa}]$ & $\mathrm{n}[-]$ & $\mathrm{q}_{\mathrm{d}}[\mathrm{MPa}]$ & $\mathrm{q}_{\mathrm{d} ; \mathrm{a}}[\mathrm{MPa}]$ \\
\hline 26 & 4 & $17.93-23.65$ & 21.21 & 4 & $0.387-0.645$ & 0.516 \\
\hline 48 & 4 & $23.65-25.25$ & 24.45 & 4 & $0.516-0.645$ & 0.613 \\
\hline 66 & 4 & $21.23-27,62$ & 25.23 & 4 & $0.774-1.033$ & 0.936 \\
\hline 92 & 4 & $29.18-34.74$ & 33.39 & 4 & $0.904-1.162$ & 1.033 \\
\hline 115 & 4 & $34.50-36.72$ & 35.98 & 4 & $1.033-1.291$ & 1.129 \\
\hline
\end{tabular}

The calculated value of the index of soil's sensitivity from the vane field test had the range from 1.29 to 1.77 so it was less 2.0 , than tested material classified as insensitive soil. The state of tested soil (consistency) on the base of undrained shear strength from FVT, which ranged from 17.93 to $36.72 \mathrm{kPa}$, was estimated as soft $\left(\mathrm{I}_{\mathrm{c}}<0.50\right)$.

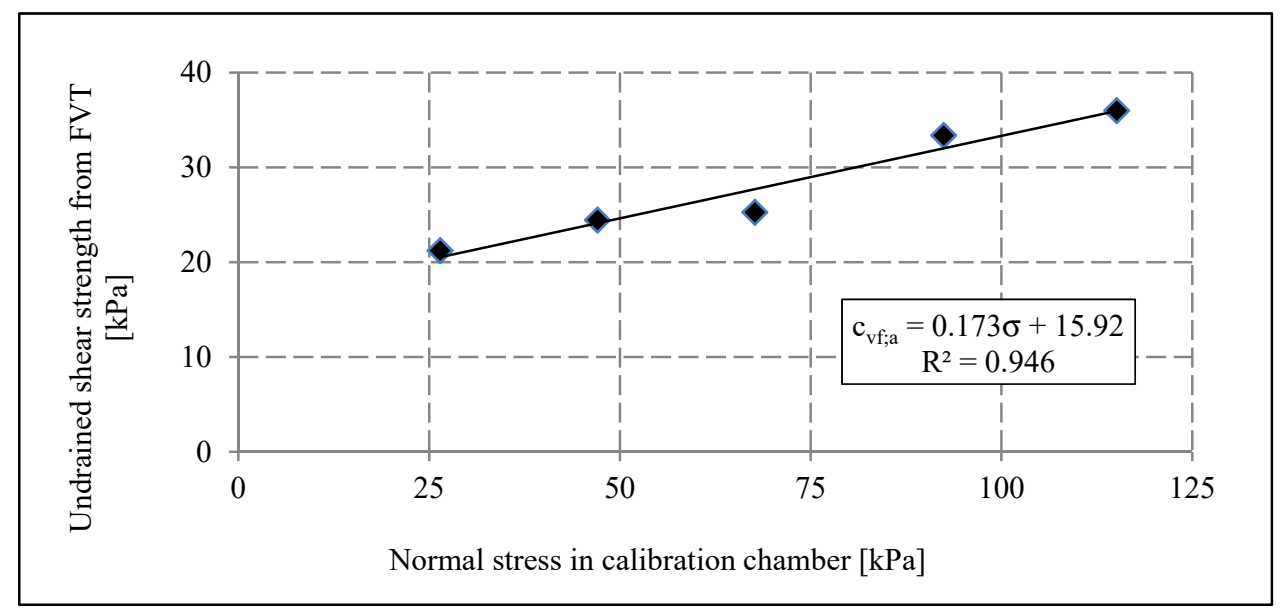

Fig. 4. The correlation between undrained shear strength from FVT and stress in calibration chamber. 
The correlations between the undrained shear strength from the field vane test or boundary strength of soil under the cone from dynamic probing and stress in the calibration chamber were presented in order: figure no. 4 and 5. In both cases the obtained very high values of coefficient of determination $\mathrm{R}^{2}$ ( 0.946 for FVT and 0.964 for DPL) testifies to the strength of this simple relationship and possibilities, and the correctness of the test carried out in the chamber calibration operation.

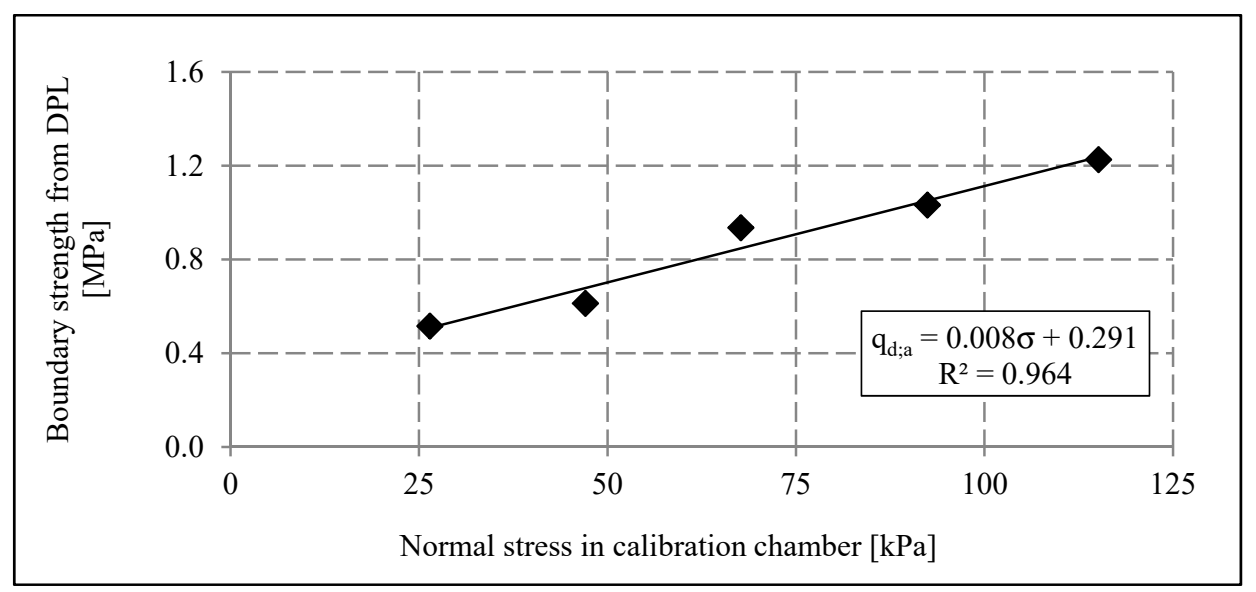

Fig. 5. The correlation between the boundary strength of the soil from DPL and the stress in the calibration chamber.

The analysis of results of conducted preliminary research search for dependencies between undistributed shear strength from field vane testing and boundary strength of soil under cone from dynamic probing. It has also showed the strong relationship because the coefficient value of determination was 0.847 . Due to the relatively small number of tests which have been done so far, results can't be considered as final and research should be repeated in the biggest range and numbers but the hitherto obtained results of the test confirmed the correctness of the accepted thesis and the direction of research.

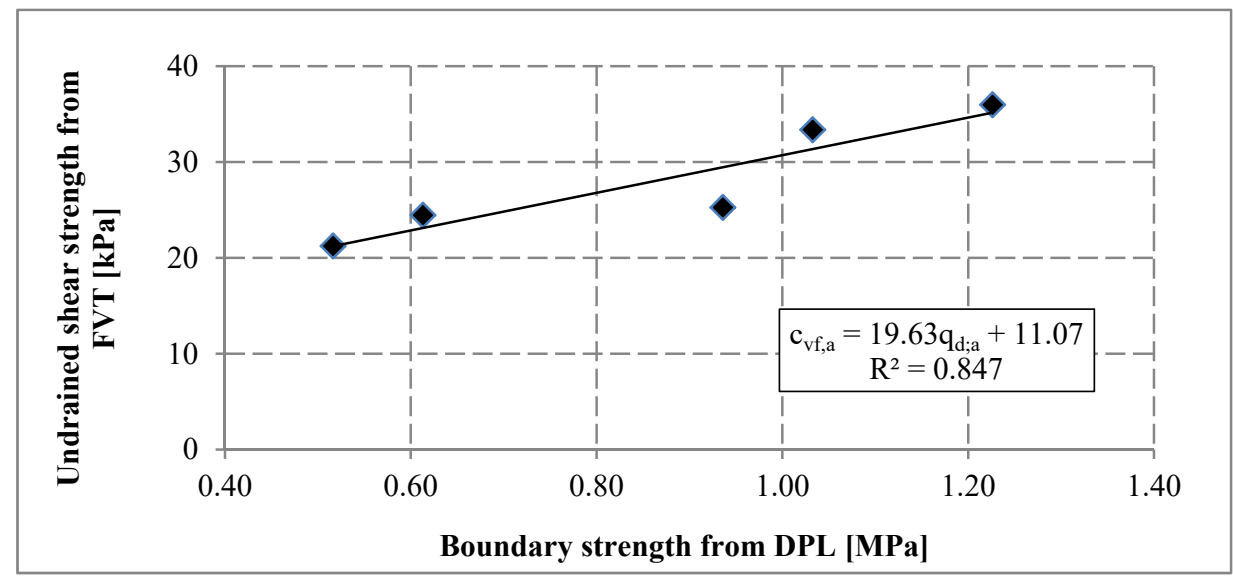

Fig. 6. The comparison of penetration resistance for organic material in the calibration chamber: relation of boundary strength of soil under cone from DPL and undistributed shear strength from FVT. 


\section{Conclusions}

The preliminary tests confirmed the suitability of the calibration chamber for testing organic soils and its great potential. The dimensions of the chamber allow for carrying out many different tests on one sample, and therefore in identical conditions. The comparison of the results of preliminary strength tests in the calibration chamber showed that for the selected type of organic soil are available relationships between the values of strength parameters obtained from rotational and dynamic soundings. It should be presumed that in the case of other weak soils, i.e. differing in the content of organic parts, moisture or volumetric weight will be similar. The confirmation of dependence between the different types of soundings will enable their variable use, which is of great importance due to the simplification of research, increasing accuracy and shortening their duration. Not without significance is the possibility of increasing the range of the probing depth, which in the case of the DPL probe is much larger than the FVP and consequently, the increase in the number of measurements due to the compaction of reading the measured values. The empirical part of this paper searches for dependencies between tests in the calibration chamber and classical laboratory methods in the aspect of their use for the development of a method for rapid estimation of the soil condition in "in situ" conditions by means of a dynamic probe that is planned at the subsequent stages of the research. Of course, the research is currently at an early stage, and confirmation of this thesis requires extensive and comprehensive research, which the author of this study intends to carry out in the near future. However, it should be remembered that in the case of organic soils, characterized by an extremely complex construction of a backbone, they are subject to continuous mineralization processes or humification at a rate depending on local residual conditions. These studies in turn, will unfortunately be labor-intensive and long-lasting.

Acknowledgement. The author is sincerely grateful to PIOTR KAWALEC DEWELOPER APKLAN from Rzeszow for the permission to use the technical documentation and the help in obtaining soil samples.

\section{References}

1. EN 1997-2: 2007. Eurocode 7 - Geotechnical design - Part 2: Ground investigation and testing (2007)

2. T. Godlewski, Ł. Kaczyński, Przegląd Naukowy - Inżynieria i Kształtowanie Środowiska, 25 (3), 356-365 (2016)

3. prEN ISO 22476-9:2007. Ground investigation and testing - Field testing - Part 9: Field vane test (2007)

4. EN ISO 22476-2: 2005. Geotechnical investigation and testing - Field testing - Part 2: Dynamic probing (2005)

5. Z. Frankowski, Interprestcja wyników sondowań dynamicznych i badań presjmetrycznych, (Nowoczesne metody badań gruntów, Sympozjum ITB, Warszawa, Poland, 2003)

6. S. Rybicki, P. Krotoszyński, Biuletyn P.I.G., 446, 397-406 (2011)

7. L. Bałachowski, Archives of Hydro-Engineering and Environmental Mechanics, 53(4), 311-329 (2006)

8. P. Kanty, S. Kwiecień, J. Sękowski, Wpływ formowania wbijanej kolumny kamiennej na otoczenie gruntowe, (Wydawnictwo P.Ś., Gliwice: ISBN 978-83-7880-304-1 2015)

9. Projekt badawczy KBN nr T07E 01012: Nowa metodyka oceny nośności nasypów budowlanych na silnie odksztatcalnym podtożu, (Politechnika Warszawska, Instytut Zaopatrzenia w Wodę i Budownictwa Wodnego, Warszawa, 1999) 
10. Z. Lechowicz, A. Szymański, Odksztatcenia i stateczność nasypów na gruntach organicznych. Cz. I. Metodyka badań. (Wydawnictwo SGGW, Warszawa, ISBN 837244-398-8, 2002)

11. Budowa budynku mieszkalnego wielorodzinnego $z$ wewnętrznym układem komunikacyjnym z garażem nadziemnym $i$ podziemnym, niezbędnymi urzadzeniami budowlanymi, infrastruktura techniczna, oświetleniem zewnętrznym $i$ miejscami postojowymi ... przy ul. Witolda w Rzeszowie, (Dokumentacja techniczna, GeoTech S-ka z o.o. for PIOTR KAWALEC DEWELOPER APKLAN, Rzeszow, 2017)

12. EN ISO 14688-2 : 2004. Geotechnical investigation and testing - Identification and classification of soil - Part 2: Principles for a classification (2004)

13. Straż G., $O$ niektórych problemach zwiazanych $z$ określaniem parametrów geotechnicznych rzeszowskich gruntów organicznych, ( XI KNDWB' 2011, J. Bzówka (eds.) Szczyrk, Poland: ISBN 978-83-7335-815-7, 143-149, 2011)

14. G. Straż, Parametry wytrzymałościowe rzeszowskich namułów i torfów, Oficyna Wydawnicza Politechniki Rzeszowskiej, (Rzeszów, ISBN 978-83-7199-690-0 2011).

15. PN-B-04452: 2002. Geotechnika. Badania polowe (2002)

16. G. Straż, JCEEA, 63 (34), 91-101 (2017) 